\title{
Bacterial extracts for the control of Atta cephalotes (Hymenoptera: Formicidae) and its symbiotic fungus Leucoagaricus gongylophorus (Agaricales: Agaricaceae)
}

\author{
Miguel Uribe Londoño ${ }^{1}$, Magally Romero-Tabarez ${ }^{1,2}$, Adriana Ortiz-Reyes ${ }^{1,2,{ }^{*}}$ \\ 1. Grupo de Investigación en Sustancias Activas y Biotecnología (SaBio), Universidad Nacional de Colombia, 050034 \\ Medellín, Colombia; miguribelon@unal.edu.co \\ 2. Escuela de Biociencias, Facultad de Ciencias, Universidad Nacional de Colombia, Medellín; \\ mromerota@unal.edu.co, adortizr@unal.edu.co \\ * Correspondence
}

Received 27-III-2019. Corrected 15-VII-2019. Accepted 05-VIII-2019.

\begin{abstract}
Introduction: Leaf-cutting ants Atta cephalotes (Linnaeus) are one of the main insect pests in Latin America; these ants (along with Acromyrmex spp.) present a unique characteristic amongst ants, - the cultivation of the Leucoagaricus gongylophorus Möller (Singer) fungus as a food source. They belong to tribe Attini and build nests in underground chambers which are interconnected by pathways. These voracious ants have attacked over 45 crop fields in Colombia. The main control method has been the use of synthetic chemical products; however, alternative control measures must be established. One alternative that has a great potential are bacteria and their secondary metabolites. Objective: The aim of this study was to evaluate the insecticidal and antifungal effect of bacterial extracts on major worker A. cephalotes ants and the L. gongylophorus fungus. Methods: A total of 118 extracts produced by the same number of bacteria were evaluated. Among the strains that produced the active extracts were: Serratia sp., Xenorhabdus nematophila, Photorhabdus sp., and Bacillus thuringiensis. From each bacterium, extracts were prepared to test both insecticidal and repellent activity on worker ants, also to evaluate growth inhibition assays on L. gongylophorus. Results: Seventeen extracts showed insecticidal activity upon contact, 13 by ingestion, while 8 showed antifungal activity that was statistically significant. In total, 23 bacterial extracts exhibited some type of activity to control Atta cephalotes. Conclusions: The results show 23 bacterial extracts with some type of activity to control A. cephalotes, which exposes the potential there is to explore bacteria, especially entomopathogenic bacteria, which may contain interesting genes for the biological control of insects.
\end{abstract}

Key words: antifungal bioassay; bacteria; contact toxicity; ingestion bioassay; leaf-cutting ants.

Uribe Londoño, M., Romero-Tabarez, M., Ortiz-Reyes, A. (2019). Bacterial extracts for the control of Atta cephalotes (Hymenoptera: Formicidae) and its symbiotic fungus Leucoagaricus gongylophorus (Agaricales: Agaricaceae). Revista de Biología Tropical, 67(4), 1010-1022.

The search for new strategies for pest control has increased over the past years as a result of the issues caused by toxic waste in the environment, in health, and most recently the negative effects on pollinators. Controlling leaf-cutting ants has become a challenge for various associations within the agriculture and forestry sectors (Diaz Napal et al., 2015; Della Lucia, Gandra, \& Guedes, 2014) and has even been considered an urban plague, as has been reported in the city of Cali, Colombia (Montoya-Lerma, Giraldo-Echeverri, Armbrecht, \& Farji-Brener, \& Calle, 2012). Traditionally, broad-spectrum chemicals have been used for 
pest control; however, due to the problems caused by the compounds, some are no longer available, which has led to a search for new alternatives.

The literature reports studies in the field of biological control and natural products of botanical origin, such as entomopathogenic and antagonistic fungi of the symbiotic fungus (Diehl-Fleig \& Valim-Labres, 1993; Ortiz \& Orduz, 2001; Lopez \& Orduz, 2003; Verma, Brar, Tyagi, Surampalli, \& Valéro, 2007), parasitoids specialized in attacking worker ants (Tonhasca, Bragança \& Erthal, 2001; Cochet, Ortega-León, \& Ortiz-Reyes, 2017), entomopathogenic nematodes (Boaretto \& Forti, 1997; Leite, 2011), and botanical extracts, which depending on the activity of secondary metabolites present, may have toxic effects on ants, alter worker ant behavior or inhibit the growth of the symbiotic fungus (Fernandes et al., 2002; Oliveira, 2006; Boulogne, Ozier-Lafontaine, Germosén-Robineau, Desfontaines, \& Loranger-Merciris, 2012; Diaz Napal et al., 2015; Rodriguez, Montoya-Lerma, \& Calle, 2015; Lobo-Echeverri, Salazar, Hernández, \& Ortiz-Reyes, 2016).

However, these results have not been completely satisfactory due to the complexity of the ant nests and their defense strategies (Della Lucia et al., 2014; Currie \& Stuart, 2001). This is evidenced by the low number of biopesticides found on the market, making it a challenge to satisfy the growing demand for this type of product. In recent years, studies related to host-microbiota interactions have increased, revealing multiple functions carried out by the bacteria which affect the metabolism, immunity, and the general health of the host. In addition, studies have reported how bacteria associated to insects and nematodes present different types of biocidal activity that can be used as new sources of active products (Ramadhar, Beemelmanns, Currie, \& Clardy, 2014; Brachmann \& Bode, 2013; Beemelmanns, Guo, Rischer, \& Poulsen, 2016; Berasategui, Shukla, Salem, \& Kaltenpoth, 2016).

One of the best studied systems is the symbiosis between leaf-cutting ants and the symbiotic fungus Leucoagaricus gongylophorus (Currie \& Stuart, 2001; Poulsen \& Currie, 2010). This interaction depends largely on the strategies used by the ants for their maintenance, such as mechanical grooming (Currie \& Stuart, 2001), the use of substances in the metapleural gland (Yek, Nash, Jensen, \& Boomsma, 2012; Bot, Ortius-Lechner, Finster, Maile, \& Boomsma, 2002). On the other hand, a complex of bacteria, including species from the Pseudonocardia genus with antifungal activity, which selectively inhibits the parasite fungi, such as species of the Escovopsis and Trichoderma genera (Holmes et al., 2016; Marsh et al., 2013).

Bacteria associated with the immune activity are not only located in the host body, the nests are also areas rich in microorganisms that protect the colonies from pathogens. An example of this interaction is present in nests of Hymenopteran insects (Matarrita-Carranza, Moreira-Soto, Murillo-Cruz, Mora, Currie, \& Pinto-Tomas, 2017). Bacteria of the genera Streptomyces, Micromonospora, and Actinoplanes have been isolated from nests of Polistes dominulus (Christ.) (Madden, Grassetti, Soriano, \& Starks, 2013). These authors reveal a great diversity of actinomycetes isolated from the wasp nest and observe that these groups are rich in antimicrobial activity providing the nests with a mixture of active compounds that keep the colonies protected from pathogenic microorganisms. Wasps are associated to bacteria of the Streptomyces genus, which have been isolated from different species of the Philanthus, Philanthinus, and Trachypus (Crabronidae) genera; these have been closely related to the Streptomyces philanthi bacteria. The females deposit these bacteria in the tunnel where they lay their eggs. When the larvae hatch, they incorporate the bacteria into their organism, which, when forming the cocoon, is protected by two antibiotics (streptochlorin and piericidin derivatives); both compounds protect from being invaded by fungi pathogens (Kroiss et al. 2010; Kaltenpoth, Yildirim, Gürbüz, Herzner, \& Strohmd, 2012; Kaltenpoth, 
\& Engl, 2014; Nechitaylo, Westermann, \& Kaltenpoth, 2014).

Despite the fact that they are morphologically, genetically, and ecologically diverse organisms, studies conducted on nematodes are scarce (Kanfra, Liu, Beerhues, Sørensen, \& Heuer, 2018). They represent nearly 80 $\%$ of animals on Earth, making it the most abundant animal group considering number of individuals (Yeates, Ferris, \& Moens, 2009). The Caenorhabditis elegans species is used as a study model, yielding results that reflect the importance of microbiota in the life history of nematodes. Cabreiro \& Gems (2013) report the presence of approximately 10000 bacterial cells, which represents an amount ten times greater than the number of somatic cells found in the nematode. The functions of the bacteria are currently being studied, but some of the results reveal a principal role in nutrition, defense, and strategies associated to different nematode eating habits, such as predation, pathogenic action, and necromania (Cabreiro \& Gems, 2013).

The cases that have been studied the most are the species of nematodes known as entomopathogenic (Steinernema and Heterorhabditis genera); the symbiotic bacteria belonging to the Xenorhabdus and Photorhabdus genera are reportedly in charge of producing metabolites to kill the host insect, protecting them from opportunistic pathogens, and deteriorating its tissues (Goodrich-Blair \& Clarke, 2007; Bode, 2009). In recent studies, these bacteria have been isolated and cultured outside the host with the aim of generating natural products of bacterial origin for pest control; results have shown similarities in the mode of action with Bacillus thuringiensis, which is commonly used in agricultural pest control (Nielsen-LeRoux, Gaudriault, Ramarao, Lereclus, \& Givaudan, 2012). In the study reported by Fang, Zhang, Tang, Wang, \& Zhang, (2014), products filtered from the Xenorhabdus bacteria are used against phytopathogenic fungi, such as Botrytis cinerea, demonstrating fungicidal capacity of over $90 \%$. Similar results were reported by San-Blas, Carrillo, and Parra (2012), who stated that Xenorhabdus sp. and Photorhab$d u s$ sp. in axenic cultures have an antifungal effect of up to $97 \%$ on Moniliophthora roreri, causal agent of frosty pod rot disease in cacao (Theobroma cacao).

Nollmann et al. (2015) report the action of lipid compounds known as "phurealipids" (Photorhabdus urea lipids) isolated from the entomopathogenic bacterium Photorhabdus luminescens; its mode of action is very similar to that of products that inhibit the young hormone in insects. These studies show the potential of the metabolites present in bacteria associated to nematodes as sources of antifungal activity. Other nematodes, such as the Rhabditidae family, have been found associated with bacteria, such as Serratia sp., which plays a toxic role against the prey of the nematode (Tambong, 2013; Zhang et al., 2009). Bacteria with antifungal properties have also been found, such as Bacillus cereus subsp. thuringiensis (Nishanth, Mohandas, \& Nambisan, 2013; Nishanth, Nath, Pratap Chandran, \& Nambisan, 2014). However, the usefulness of many bacteria associated to nematodes remains unknown.

This study evaluated the natural extracts of bacterial origin obtained from bacteria associated to entomophilic and entomopathogenic nematodes on leaf-cutting ants and the symbiotic fungus L. gongylophorus as a control strategy combining a possible insecticidal or fungicidal action, or both.

\section{MATERIALS AND METHODS}

Nematode isolation: Two types of traps were used, the first of which was the insect trap technique described by Stock (1998). The soil samples were collected in plastic containers and taken to the Insect and Biotechnology laboratory of Universidad Nacional de Colombia (Medellín), where they were in contact with 10 larvae of fifth instar Galeria mellonella; the containers were turned so that the larvae had to come up through the soil and could be infected by the nematodes. After four days, the larvae that presented symptoms of infection by 
nematodes or presence of nematodes on the outside of the larvae were put into the White traps (White, 1927) for the recovery of the infective juveniles.

The second technique was a modification of the methodology described by Kehres, Denon, and Mauleon (2001) and Emelianoff et al. (2008). In this study, a trap was built of metal mesh where larvae of $G$. mellonella were placed and which were buried in the sampling site to allow the larvae to be infected.

The nematodes were isolates from different sub-regions of the departments of Antioquia and Caldas (Colombia), and three EPN isolates were obtained from two biological control companies. These locations were chosen because they had either well-conserved areas or plantations with good cover crops (Table 1). The isolates were codified and maintained in in vivo reproduction on the G. mellonella larvae until bacteria isolation was performed in each of the nematodes (the nematodes were macerated to obtain the external and internal bacteria).

Bacterial and fungal strains: A total of 118 bacteria were isolated from nematodes and deposited in the collection of strains and genes of the Biotechnology Institute of the Universidad Nacional de Colombia (IBUN) were used. All the strains were isolated from Colombia. Nutrient agar or NBTA agar media were employed as culture media, the latter for bacteria of the Xenorhabdus and Photorhabdus genera (Stock \& Goodrich-Blair, 2012).

The symbiotic fungus L. gongylophorus was isolated from the ant nest gardens established in the Insect and Biotechnology laboratory of Universidad Nacional de Colombia, Medellín. There, $0.5 \mathrm{~cm}^{3}$ of the fungus was taken from the upper part of the garden and placed in the laminar flow cabinet where small portions were inoculated in potato dextrose agar (PDA).

Bacterial extract collection: For the production of extracts, a total of 118 bacteria were used. Bacterial extracts were obtained according to the method proposed by Romero-Tabarez et al. (2006), in which $100 \mu \mathrm{L}$ of a previously established bacterial inoculum were inoculated in an Erlenmeyer flask with $100 \mathrm{ml}$ of nutrient broth. Also, $2.5 \mathrm{ml}$ of Amberlite XAD-16 resin was incubated for 7 days at $27{ }^{\circ} \mathrm{C}$ and 120 $\mathrm{rpm}$. The resin was recovered from the culture medium by decantation and was transferred to a solution of $15 \mathrm{ml}$ of methanol for $24 \mathrm{~h}$. The products absorbed by the resin were eluted with methanol, concentrated using a rotary evaporator (Thompson), and then suspended in $2 \mathrm{ml}$ methanol. Extracts were stored at $-4{ }^{\circ} \mathrm{C}$.

Atta cephalotes breeding: The major workers used in the study were obtained from an artificial nest of $A$. cephalotes established

TABLE 1

Sampling sites for nematodes associated to insects

\begin{tabular}{|c|c|c|}
\hline Collection site & Latitude & Longitude \\
\hline Abejorral, Antioquia & $5^{\circ} 50 ’ 55.23 ” \mathrm{~N}$ & $75^{\circ} 29^{\prime} 54.49 ” \mathrm{O}$ \\
\hline San Vicente, Antioquia & $6^{\circ} 15^{\prime} 0^{\prime \prime} \mathrm{N}$ & $75022 ’ 32 ” O$ \\
\hline El Retiro, Antioquia & $6^{\circ} 04^{\prime} 39.87^{\prime \prime} \mathrm{N}$ & $75^{\circ} 29^{\prime} 47.01^{\prime \prime} \mathrm{O}$ \\
\hline Manizales, Caldas & $5^{\circ} 2^{\prime} 42.86^{\prime \prime} \mathrm{N}$ & $75^{\circ} 25^{\prime} 1.17^{\prime \prime} \mathrm{O}$ \\
\hline Manizales, Caldas & $5^{\circ} 0 \prime 13.76^{\prime \prime} \mathrm{N}$ & $75^{\circ} 25^{\prime} 58.22 ” \mathrm{O}$ \\
\hline Chinchiná, Caldas & $4^{\circ} 57^{\prime} 39.64 ” \mathrm{~N}$ & $75^{\circ} 40^{\prime} 3.97^{\prime \prime} \mathrm{O}$ \\
\hline Fredonia, Antioquia & $5^{\circ} 46^{\prime} 28^{\prime \prime} \mathrm{N}$ & $75^{\circ} 37^{\prime} 46^{\prime \prime} \mathrm{O}$ \\
\hline Medellín, Antioquia & $6^{\circ} 15^{\prime} 40^{\prime \prime} \mathrm{N}$ & $75^{\circ} 34^{\prime} 39^{\prime \prime} \mathrm{O}$ \\
\hline Vereda San Cristóbal, Antioquia & $6^{\circ} 17^{\prime} 34.30 ” \mathrm{~N}$ & $75^{\circ} 37^{\prime} 23.34 ” \mathrm{O}$ \\
\hline Medellín, Antioquia & $6^{\circ} 10^{\prime} 17.61 ” \mathrm{~N}$ & $75^{\circ} 38^{\prime} 3.82^{\prime \prime} \mathrm{O}$ \\
\hline Rio Negro, Antioquia & $6^{\circ} 07^{\prime} 52^{\prime \prime} \mathrm{N}$ & $75^{\circ} 27^{\prime} 0.6^{\prime \prime} \mathrm{O}$ \\
\hline Rio Negro, Antioquia & $6^{\circ} 07^{\prime} 50.77^{\prime \prime} \mathrm{N}$ & $75^{\circ} 27^{\prime} 57.83^{\prime \prime} \mathrm{O}$ \\
\hline Santa Elena, Antioquia & $6^{\circ} 15^{\prime} 38^{\prime \prime} \mathrm{N}$ & $75^{\circ} 30^{\prime} 23^{\prime \prime} \mathrm{O}$ \\
\hline
\end{tabular}


at the Insect and Biotechnology laboratory of Universidad Nacional de Colombia, Medellín. The colony was maintained using leaves from the copperleaf plant (Acalypha wilkesiana), lemon leaves (Citrus sp.), and country almond (Terminalia catappa) at an average temperature of $25.1{ }^{\circ} \mathrm{C}$, average humidity of $57.8 \%$, as well as by periodically cleaning the nest. The symbiotic fungus L. gongylophorus was isolated from ant gardens where small portions were seeded in potato dextrose agar (PDA) medium.

Screening of extracts: An initial screening was conducted in which the 118 extracts produced were evaluated. This bioassay was based on the methodology proposed by Boulogne et al. (2011). In a $50 \mathrm{~mm}$ Petri dish with filter paper at the bottom, $500 \mu \mathrm{L}$ of each bacterial extract or distilled water were applied to the control. Five worker ants were placed inside; in order to ensure that death was not due to lack of food, the artificial diet described by Bueno, Morini, Pagnocca, Hebling, \& Silva (1997) was supplied. Dead ants were counted every $24 \mathrm{~h}$ for 5 days. The extracts showing activity were selected for the contact and ingestion bioassays.

Insecticide bioassay: Contact toxicity, this bioassay was based on the methodology proposed by Boulogne et al. (2011). In a $50 \mathrm{~mm}$ Petri dish with filter paper at the bottom, 500 $\mu \mathrm{L}$ of each bacterial extract or distilled water were applied to the control. Five worker ants were placed inside; in order to ensure that death was not due to lack of food, the artificial diet described by Bueno et al. (1997) was supplied. Dead ants were counted every $24 \mathrm{~h}$ for 5 days. Bioassays were performed in triplicate for each extract.

Ingestion bioassay, for this bioassay, five worker ants were placed in a $90 \mathrm{~mm}$ Petri dish and was supplied an $8 \mathrm{~mm}$ diet cube every $24 \mathrm{~h}$ which contained either the bacterial extract, or methanol as control. The diet was prepared in a $50 \mathrm{~mm}$ Petri dish with $10 \mathrm{ml}$ of artificial diet and $400 \mu \mathrm{L}$ of bacterial extract. Dead ants were counted every $24 \mathrm{~h}$ for 5 days. Bioassays were performed in triplicate for each extract.
Antifungal bioassay: For this bioassay, the 118 extracts were evaluated initially. The bioassay consisted in using $50 \mathrm{~mm}$ Petri dishes containing $10 \mathrm{ml}$ of PDA nutrient medium to which $400 \mu \mathrm{L}$ of bacterial extract was added during preparation of $400 \mu \mathrm{L}$ of methanol for the controls. After solidification, an $8 \mathrm{~mm}$ hole was drilled in the middle of the Petri dish where a portion of the fungus with the same diameter taken from a one-month-old culture was placed; it was kept in a climatic chamber at $25{ }^{\circ} \mathrm{C}$ and $60 \%$ relative humidity. For each extract, three repetitions were performed as well as one control. The area of growth was measured using ImageJ version 1.49q (Schneider, Rasband, \& Eliceiri, 2012.) software each week for 5 weeks. The equation used by Boulogne et al. (2011) was applied to calculate the percentage inhibition of radial growth.

Identifying extracts with greatest activity: In order to identify the extracts that had the greatest effect, those that killed $100 \%$ of the leaf-cutting ants in less than $48 \mathrm{~h}$ in the contact toxicity bioassay were selected. In the ingestion and antifungal bioassays, cumulative mortality over time was integrated, resulting in a technique known as area under the curve of cumulative mortality. The information of the area under the curve was collected using SAS statistical software (SAS Institute Inc., 2004), after which variance analysis was performed generating the least significant difference that each treatment must meet in order to be statistically different from the control, for which Dunnett's test was used.

Identification of bacterial strains: Bacteria producing the most active extracts in the bioassays were identified using Biolog ${ }^{\circledR}$ ID system GEN III, which performs 96 simultaneous biochemical tests and compares the results with a database.

\section{RESULTS}

Insecticide bioassay: In the contact toxicity bioassay, five of the bacterial extracts evaluated - 699 (Bacillus thuringiensis/cereus), 706 (Serratia marcescens ss marcescens), 788 
(Escherichia hermannii), 794 (Delftia tsuruhatensis), and 797 (Acinetobacter beijerinckii)killed $100 \%$ of the ants in less than $24 \mathrm{~h}$. It is important to mention that other 12 extracts killed $100 \%$ of the ants in less than $48 \mathrm{~h}$ (Table 4 and Fig. 1A, Fig. 1B).

In the ingestion bioassay, the least significant difference (LSD) was 8.31 (area under the curve) at $48 \mathrm{~h}$, demonstrating that 13 of the bacterial extracts had statistically significant differences (Table 2) (Fig. 1C, Fig 1D). At $72 \mathrm{~h}$ following the beginning of the bioassay, 13 bacterial extracts had killed up to $93 \%$ of the ants. This group included the following extracts: $699,706,757,775,797$, and 802 , amongst others (Table 2 and Table 4). It should be noted that bacterial extract 793 was statistically significant at $24 \mathrm{~h}$.

Extracts 801 and 808 were not representative in the ingestion bioassay; this could be due to the fact that the ants completely rejected the diet administered, and thus, did not consume the extract (Fig. 1C).

Antifungal bioassay: The following eight bacterial extracts had an antifungal effect on $L$. gongylophorus: 715, 716, 758, 759, 771, 801, 802, and 808 (Table 3, Table 4, Fig. 2A, Fig. 2B, Fig. 2C and Fig. 2D). For the antifungal bioassay, LSD was 10.35 (area under the curve) (Table 3).

Bacterial strains: Bacteria producing most active extracts in the bioassays were identified (Table 4).

\section{DISCUSSION}

The results show a total of 23 extracts with activity, which represents $23.7 \%$ of the
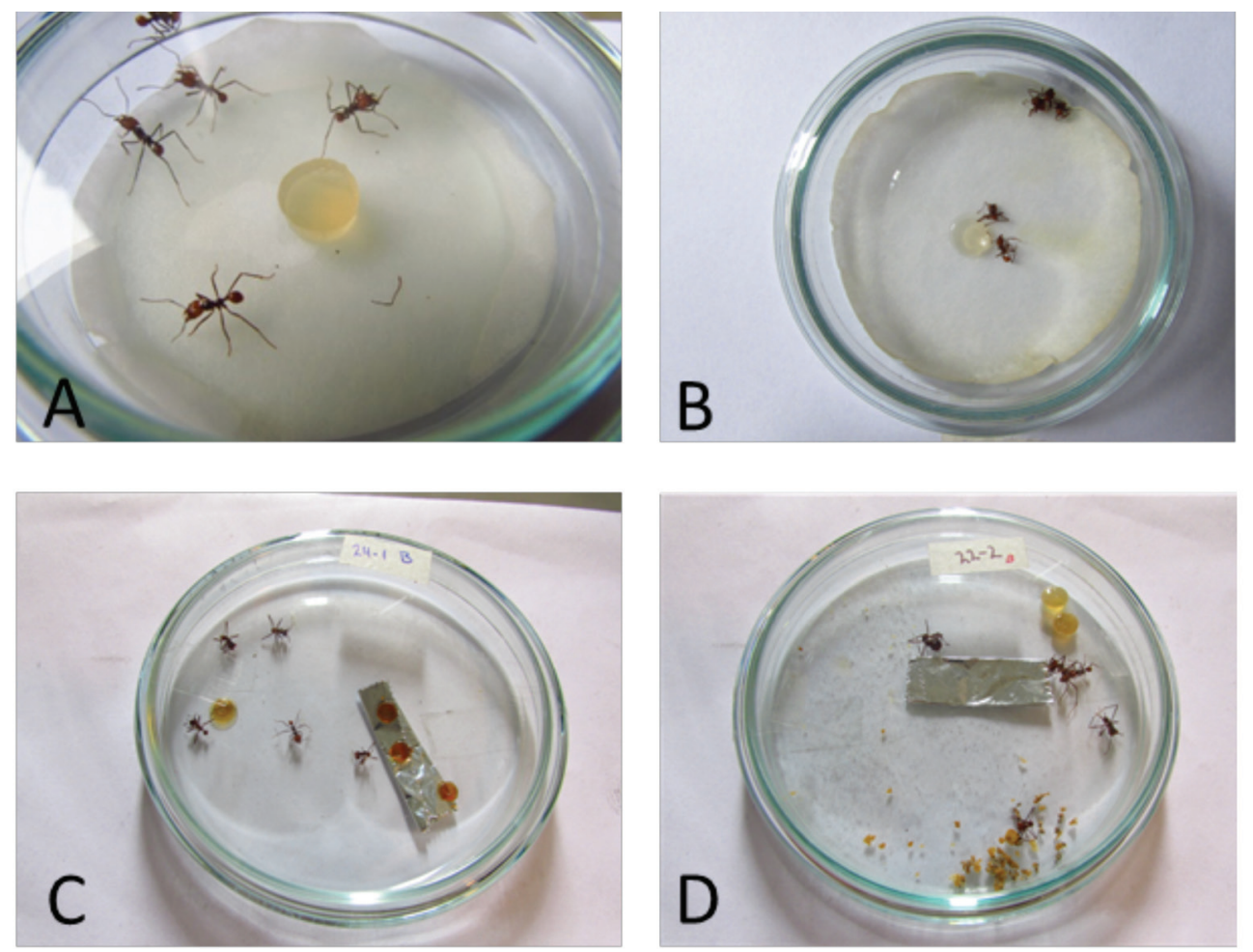

Fig. 1. Examples of contact toxicity bioassay, in which A) shows live ants after 24 hours (control), and B) shows the dead ants after the same time period (treated); Examples of ingestion bioassay. In C) the control ants were still alive after 120 hours, whereas in D) the treated ants died. 
TABLE 2

Comparison of treatments with respect to the control in the ingestion bioassay.

Least significant difference (LSD) was found

\begin{tabular}{cc} 
Bacterial Extract & Average \\
797 & $17333^{* * *}$ \\
706 & $16167^{* * *}$ \\
793 & $15833^{* * *}$ \\
699 & $15500^{* * *}$ \\
798 & $15000^{* * *}$ \\
789 & $14333^{* * *}$ \\
740 & $13833^{* * *}$ \\
792 & $13500^{* * *}$ \\
775 & $12500^{* * *}$ \\
802 & $12500^{* * *}$ \\
757 & $12333^{* * *}$ \\
759 & $11667 * *$ \\
788 & $11000^{* * *}$ \\
705 & 7.167 \\
716 & 7.167 \\
794 & 6.500 \\
715 & 6.000 \\
801 & 6.000 \\
808 & 5.333 \\
725 & 5.000 \\
\hline
\end{tabular}

*** Bacterial extracts with LSD when compared to the control.
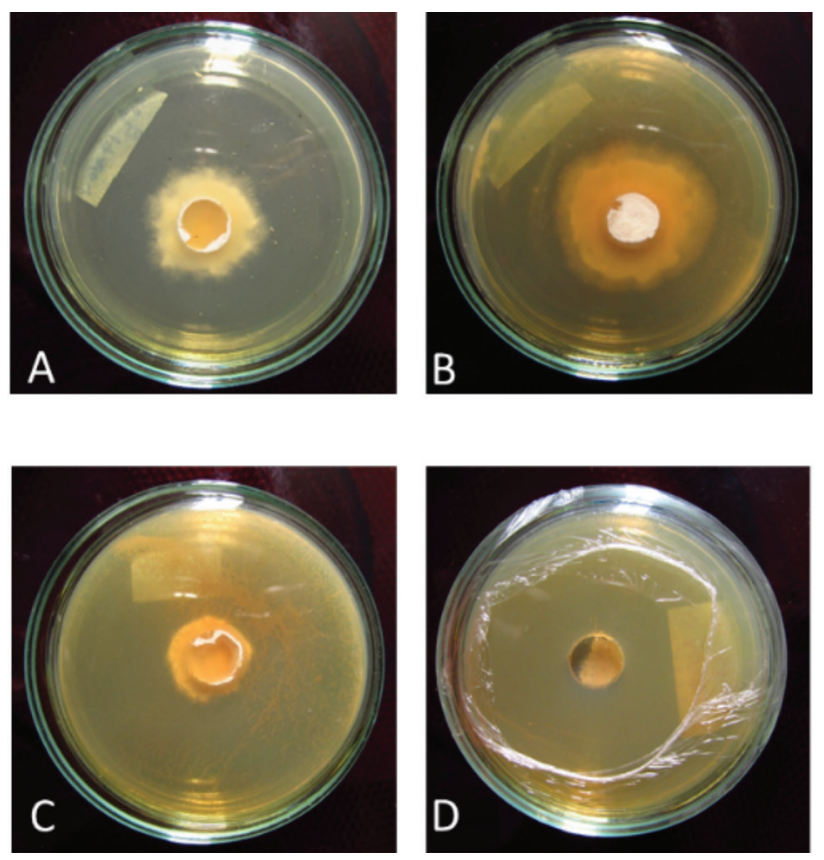

Fig. 2. Antifungal bioassay (bottom of Petri dishes). L. gongylophorus in different treatments after 5 weeks in culture medium containing the bacterial extracts A) Control B) 705 C) 802 D) 808. 
TABLE 4

General results for insecticide and antifungal bioassays

\begin{tabular}{|c|c|c|c|c|c|}
\hline Strain Code & Extract & Bacteria Identified & Antifungal & Ingestion & Contact \\
\hline IBUN-090-00797 & 797 & Acinetobacter beijerinckii & & $\mathrm{xxx}$ & $\mathrm{xxx}$ \\
\hline IBUN-090-00705 & 705 & Bacillus amyloliquefaciens ss amyloliquefaciens & & & $\mathrm{xx}$ \\
\hline IBUN-090-00699 & 699 & Bacillus thuringiensis/cereus & & $\mathrm{xxx}$ & $\mathrm{xxx}$ \\
\hline IBUN-090-00725 & 725 & Brevundimonas diminuta & & & $\mathrm{x}$ \\
\hline IBUN-090-00794 & 794 & Delftia tsuruhatensis & & & $\mathrm{xxx}$ \\
\hline IBUN-090-00788 & 788 & Escherichia hermannii & & $\mathrm{x}$ & $\mathrm{xxx}$ \\
\hline IBUN-090-00799 & 799 & No Id (IBUN-090-00799) & & & $\mathrm{x}$ \\
\hline IBUN-090-00715 & 715 & No Id (IBUN-090-00715) & $\mathrm{x}$ & & \\
\hline IBUN-090-00740 & 740 & No Id (IBUN-090-00740) & & $\mathrm{xx}$ & $\mathrm{x}$ \\
\hline IBUN-090-00802 & 802 & Photorhabdus sp. & $\mathrm{xxx}$ & $\mathrm{xx}$ & \\
\hline IBUN-090-00741 & 741 & Pseudomonas aeruginosa & $\mathrm{x}$ & $\mathrm{x}$ & $\mathrm{x}$ \\
\hline IBUN-090-00758 & 758 & Pseudomonas aeruginosa & $\mathrm{x}$ & & \\
\hline IBUN-090-00716 & 716 & Pseudomonas chlororaphis ss aurantiaca & $\mathrm{X}$ & & $\mathrm{x}$ \\
\hline IBUN-090-00771 & 771 & Pseudomonas marginalis & $\mathrm{XX}$ & & \\
\hline IBUN-090-00792 & 792 & Pseudomonas nitroreducens & & $\mathrm{xx}$ & $\mathrm{xx}$ \\
\hline IBUN-090-00757 & 757 & Pseudomonas tolaasii & & $\mathrm{x}$ & \\
\hline IBUN-090-00775 & 775 & Serratia liquefaciens & & $\mathrm{xx}$ & $\mathrm{x}$ \\
\hline IBUN-090-00789 & 789 & Serratia liquefaciens/grimesii & & $\mathrm{xx}$ & $\mathrm{x}$ \\
\hline IBUN-090-00706 & 706 & Serratia marcescens ss marcescens & & $\mathrm{xxx}$ & $\mathrm{xxx}$ \\
\hline IBUN-090-00793 & 793 & Serratia marcescens ss marcescens & & $\mathrm{xxx}$ & $\mathrm{x}$ \\
\hline IBUN-090-00798 & 798 & Serratia marcescens ss marcescens & & $\mathrm{xxx}$ & $\mathrm{x}$ \\
\hline IBUN-090-00808 & 808 & Xenorhabdus nematophila & $\mathrm{xxx}$ & & $\mathrm{xx}$ \\
\hline IBUN-090-00801 & 801 & Xenorhabdus sp. & $\mathrm{xxx}$ & & \\
\hline
\end{tabular}

*Each "X" represents the level of response for each bioassay. For example, Xenorhabdus and Photorhabdus bacteria presented the most inhibition of the Leucoagaricus gongylophorus fungus in the antifungal bioassay.

total, $14.4 \%$ with insecticidal activity, $11 \%$ by ingestion and $6.8 \%$ with antifungal activity against the L. gongylophorus fungus. In this study, five bacterial extracts were found which killed $100 \%$ of the ants within $24 \mathrm{~h}$ in the contact toxicity bioassay; the active extracts at $48 \mathrm{~h}$ represent $14.4 \%$ of the extracts evaluated, which represents a promising result due to the quick action they could exert on the ant populations of a colony, drastically affecting the nest. The species with greatest insecticide activity was Serratia marcescens ss marcescens IBUN-090-00706, which has been reported in previous studies (Inglis \& Lawrence, 2001; Ashelford, Fry, Bailey, \& Day, 2002; Jeong et al., 2010; Patil, Patil, Salunke, \& Salunkhe, 2011), demonstrating its potential as an entomopathogenic bacteria. Another promising species was Pseudomonas chlororaphis ss aurantiaca IBUN-090-00716, which agrees with the study by Ruffner et al. (2013), who reported oral insecticidal activity of this bacterium on Spodoptera littoralis, Heliothis virescens, and Plutella xylostella - three insects belonging to the Lepidoptera order. The pathogenicity of this bacterium is due to Fit toxins, which are different from those found in bacteria, such as Xenorhabdus, Photorhabdus, and Serratia sp.

The extract of $S$. marcescens marcescens IBUN-090-00706 presented insecticide activity by ingestion. This result is in concordance with the study of Tambong et al. (2014), in which the authors reported insecticidal activity against Galleria mellonella. However, the methodology was different as they injected 
active bacterial cells directly into the insect hemocele (most studies on entomopathogenic bacteria are done this way), contrary to this study, in which the insecticidal capacity of extracts without active bacterial cells was evaluated; in the case of this bioassay, extracts were demonstrated to act by ingestion against leaf-cutting ants.

The article published by Hurst, Glare, Jackson, \& Ronson (2000) also proves the oral capacity of the Serratia genus, in which they tested Serratia entomophila and S. proteamaculans these bacterias cause amber disease in the grass grub Costelytra zealandica (Coleoptera: Scarabaeidae), an important pasture pest in New Zealand. Larval disease symptoms include cessation of feeding, clearance of the gut, amber coloration, and eventual death. The extract of Pseudomonas tolaasii IBUN090-00757 presented insecticidal activity by ingestion, which has not been reported in the literature. The extract produced by Photorhabdus sp. IBUN-090-00802 presented insecticidal activity by ingestion, showing statistical difference from the control; this result may be compared to different studies that show the oral pathogenic capacity presented by this bacterial genus, such as the study reported by Guo et al. (1999). These authors demonstrated the oral insecticidal capacity exerted by Photorhabdus luminescens W-14 on the Diabrotica undecimpunctata (Coleoptera Chrysomelidae) larvae - pests common in corn fields. One of the few studies that used bacteria from the Photorhab$d u s$ genus against leaf-cutting ants is the one by De Paula et al. (2006); however, the authors did not conduct oral insecticidal activity tests, but rather contact and repellent bioassays.

The three bacterial extracts that most caused inhibition in the antifungal bioassay were Xenorhabdus sp. IBUN-090-00801, Photorhabdus sp. IBUN-090-00802, and Xenorhabdus nematophila IBUN-090-00808, which also showed good results in the insecticide bioassay. The extracts of Xenorhabdus sp. IBUN-090-00801 and Xenorhabdus nematophila IBUN-090-00808 were positive for the contact toxicity bioassay. These bacteria belonging to the Xenorhabdus genus present antifungal activity previously reported in the literature; studies are generally focused on the handling of phytopathogenic fungi (Goodrich-Blair, \& Clarke 2007; Fang, Zhang, Tang, Wang, \& Zhang., 2014; San-Blas et al., 2012). In one of these studies, by Böszörményi et al. (2009), they found that the compounds produced by $X$. budapestensis were absorbed by Amberlite XAD-1180 resin (similar to what was used in this study); one of the isolates is an oligopeptide known as bicornutin A.

Other bacterial extracts that produced an antifungal effect were $P$. chlororaphis aurantiaca IBUN-090-00716 and $P$. marginalis IBUN-090-00771. P. chlororaphis aurantiaca has been reported as a plant growth promoter, which increases the absorption of phosphorus; additionally, a genome sequencing study revealed genes involved in antifungal products (Calderón, Ramos, de Vicente, \& Cazorla, 2015). P. marginalis has been reported as phytopathogenic in alfalfa (Medicago sativa), in which synergy of this bacteria with Meloidogyne hapla (phytopathogenic nematode) for the infection of the roots of this plant has been reported; however, there are no reports of antifungal activity for $P$. marginalis. Reports of these two bacteria are different associations in the radicular zone of the plants. They may possess antifungal substances which limit growth of opportunistic fungi of the rhizosphere. This explains the positive results regarding the antifungal activity against L. gongylophorus.

It should be noted that for most tested and identified bacteria there is little reference to them as being insecticidal or antifungal, such as $A$. beijerinckii and $P$. nitroreducens, which have been reported as hydrocarbon degraders (Huang et al., 2013; West, 2014); nonetheless, their activity was important in this study.

Ethical statement: authors declare that they all agree with this publication and made significant contributions; that there is no conflict of interest of any kind; and that we followed all pertinent ethical and legal procedures and requirements. All financial sources are 
fully and clearly stated in the acknowledgements section. A signed document has been filed in the journal archives.

\section{ACKNOWLEDGMENTS}

The authors would like to thank Guillermo Correa for his assistance with the statistical aspect as well as anonymous evaluators who contributed to the improvement of the manuscript. This study was supported by the Universidad Nacional de Colombia, code (22218 - 28676 - 27694); This research was carry out under the Contract Number 145 of 2017 (Ministerio de Medio Ambiente y Desarrollo Sostenible - Universidad Nacional de Colombia) "Contrato de Acceso a Recursos Genéticos y Productos derivados".

\section{RESUMEN}

Extractos bacterianos para el control de Atta cephalotes (Hymenoptera: Formicidae) y su hongo simbiótico Leucoagaricus gongylophorus (Agaricales: Agaricaceae). Introducción: Las hormigas cortadoras de hojas (Atta cephalotes) son una de las mayores plagas en América Tropical, estas hormigas (junto con Acromyrmex spp.) presentan una característica única entre las hormigas - el cultivo de un hongo como fuente de alimento (Leucoagaricus gongylophorus). Pertenecen a la tribu Attini y construyen sus nidos en cámaras subterráneas interconectadas por caminos. En el campo son muy voraces atacando más de 45 cultivos en Colombia. La metodología de control usada para el manejo de esta plaga ha sido principalmente el uso de productos químicos sintéticos, sin embargo, es importante establecer alternativas de control. Una fuente con gran potencial son las bacterias y sus metabolitos secundarios. Objetivo: El objetivo de la presente investigación fue evaluar la acción insecticida y antifúngica de los extractos bacterianos en obreras de $A$. cephalotes y el hongo L. gongylophorus. Métodos: Un total de 118 extractos, producidos por el mismo tipo de bacterias fueron evaluados. Resultados: Entre las cepas productoras se encontraban: Serratia sp., Xenorhabdus nematophila, Photorhabdus sp. y Bacillus thuringiensis. Diecisiete extractos mostraron actividad insecticida por contacto, 13 actividad por ingestión y 8 con actividad antifúngica estadísticamente significativa. En total 23 extractos bacterianos exhibieron algún tipo de actividad para el control de Atta cephalotes. Conclusiones: Los resultados muestran 23 extractos bacterianos con algún tipo de actividad hacia el control de $A$. cephalotes, los cuales exponen el potencial que hay para explorar bacterias, en especial las entomopatógenas. Estas bacterias pueden contener genes importantes para el control biológico de insectos.

Palabras clave: antifúngico; bacterias; hormigas cortadoras de hojas; insecticida por contacto; insecticida por ingestión.

\section{REFERENCES}

Ashelford, K. E., Fry, J. C., Bailey, M. J., \& Day, M. J. (2002). Characterization of Serratia isolates from soil, ecological implications and transfer of Serratia proteamaculans subsp. quinovora Grimont et al., 1983 to Serratia quinivorans corrig., sp. nov. International Journal of Systematic and Evolutionary Microbiology, 52, 2281-9.

Boaretto, M., \& Forti, L. (1997). Perspectivas no controle de formigas cortadeiras. Série Técnica IPEF, 11(30), $31-46$.

Böszörményi, E., Érsek, T., Fodor, A., Fodor, A. M., Földes, L. S., Hevesi, M., Hogan, J. S., Katona, Z., Klein, M. G., Kormány, A., Pekár, S., Szentirmai, A., Sztaricskai, F., \& Taylor, R. A. J. (2009). Isolation and activity of Xenorhabdus antimicrobial compounds against the plant pathogens Erwinia amylovora and Phytophthora nicotianae. Journal of Applied Microbiology, 107, 746-759.

Boulogne, I., Germosen-Robineau, L., Ozier-Lafontaine, H., Jacoby-Koaly, C., Aurela, L., \& Loranger-Merciris, G. (2011). Acromyrmex octospinosus (Hymenoptera: Formicidae) management. Part 1: Effects of TRAMIL's insecticidal plant extracts. Pest Management Science, 68, 313-20.

Boulogne, I. Ozier-Lafontaine, H., Germosén-Robineau, L., Desfontaines, L., \& Loranger-Merciris, G. (2012). Acromyrmex octospinosus (Hymenoptera: Formicidae) Management: Effects of TRAMILs Fungicidal Plant Extracts. Journal of Economic Entomology, 105, 1224-1233.

Bot, A. N. M., Ortius-Lechner, K. D., Finster, K., Maile, R., \& Boomsma, J. J. (2002). Variable sensitivity of fungi and bacteria to compounds produced by the metapleural glands of leaf-cutting ants. Insectes Sociaux, 49(4), 363-370.

Beemelmanns, C., Guo, H., Rischer, M., \& Poulsen, M. (2016). Natural products from microbes associated with insects. The Beilstein Journal of Organic Chemistry, 12, 314-327.

Berasategui, A., Shukla, S., Salem, H., \& Kaltenpoth, M. (2016). Potential applications of insect symbionts in biotechnology. Applied Microbiology and Biotechnology, 100(4), 1567-77. DOI: 10.1007/ s00253-015-7186-9. 
Bode, H. B. (2009). Entomopathogenic bacteria as a source of secondary metabolites. Current Opinion in Chemical Biology, 13(2), 224-230. DOI: 10.1016/j. cbpa.2009.02.037

Brachmann, A. O., \& Bode, H. B. (2013). Identification and Bioanalysis of Natural Products from Insect Symbionts and Pathogens. In A. Vilcinskas (Ed.), Yellow Biotechnology I. Advances in Biochemical Engineering/Biotechnology (pp. 123-155). Berlin: Springer.

Bueno, O. C., Morini, M. S. C., Pagnocca, F. C., Hebling, M. J. A., \& Silva, O. A. (1997). Sobrevivência de operárias de Atta sexdens rubropilosa Forel (Hymenoptera: Formicidae) isoladas do formigueiro e alimentadas com dietas artificiais. Anais da Sociedade Entomológica do Brasil, 26, 107-113.

Calderón, C. E., Ramos, C., de Vicente, A., \& Cazorla, F. M. (2015). Comparative Genomic Analysis of Pseudomonas chlororaphis PCL1606 Reveals New Insight into Antifungal Compounds Involved in Biocontrol. Molecular Plant-Microbe Interactions, 28 , 249-60.

Cabreiro, F., \& Gems, D. (2013). Worms need microbes too: microbiota, health and aging in Caenorhabditis elegans. EMBO Molecular Medicine, 5(9), 1300-10. DOI: $10.1002 / \mathrm{emmm} .201100972$

Cochet, R. B., Ortega-León, Á. O., \& Ortiz-Reyes, A. (2017). Patrones comportamentales de fóridos (Diptera: Phoridae) parasitoides de Atta colombica (Hymenoptera: Formicidae). Revista de Biologia Tropical, 65, 461-473.

Currie, C. R., Bot, A. N. M., \& Boomsma, J. J. (2003) Experimental evidence of a tripartite mutualism: Bacteria protect ant fungus gardens from specialized parasites. Oikos, 101, 91-102. DOI:10.1034/j.1600-0706.2003.12036.x

Currie, C. R., \& Stuart, A. E. (2001) Weeding and grooming of pathogens in agriculture by ants. Proceedings of the Royal Society, 268(1471), 1033-1039. DOI:10.1098/rspb.2001.1605

De Paula, A. R., Vieira, L. P. P., Dáttilo, W. F. C., Carneiro, C. N. B., Erthal, J. M., Brito, E. S., Silva, C. P. P., \& Samuels, R. I. (2006). Patogenicidade e efeito comportamental de Photorhabdus temperata K122 nas formigas cortadeiras Acromyrmex subterraneus subterraneus e Atta laevigata (Hymenoptera: Formicidae). Biology, 68, 687-690.

Della, L. T., Gandra, L. C., \& Guedes, R. N. C. (2014). Managing leaf-cutting ants: peculiarities, trends and challenges. Pest Management Science, 70, 14-23.

Diaz Napal, G. N., Buffa, L. M., Nolli, L. C., Defagó, M. T., Valladares, G. R., Carpinella, M. C., Ruiz, G., \& Palacios, S. M. (2015). Screening of native plants from central Argentina against the leaf-cutting ant
Acromyrmex lundi (Guérin) and its symbiotic fungus. Industrial Crops and Products, 76, 275-280.

Diehl-Fleig, E., \& Valim-Labres, M. E. (1993). Fungi isolated from leaf-cutting ants Atta sexdens piriventris and Acromyrmex heyeri (Hymenoptera-Formicidae): Mucor spp. effects on Beauveria vassiana entomopathogen. Ciencia E Cultura, 45, 142-144.

Emelianoff, V., Le Brun, N., Pagès, S., Stock, S. P., Tailliez, P., Moulia, C., \& Sicard, M. (2008). Isolation and identification of entomopathogenic nematodes and their symbiotic bacteria from Hérault and Gard (Southern France). Journal of Invertebrate Pathology, 98(2), 211-217.

Fang, X., Zhang, M., Tang, Q., Wang, Y., \& Zhang, X. (2014). Inhibitory effect of Xenorhabdus nematophila TB on plant pathogens Phytophthora capsici and Botrytis cinerea in vitro and in planta. Scientific Reports, 4, 1-7.

Fernandes, J. B., Valmir, D., Facchini, P. H., da Silva, M. F., Rodrigues, E. E. R., \& Vieira, P.C. (2002) Extrações de óleos de sementes de citros e suas atividades sobre a formiga cortadeira Atta sexdens e seu fungo simbionte. Química Nova, 25, 1091-1095.

Goodrich-Blair, H., \& Clarke, D. J. (2007). Mutualism and pathogenesis in Xenorhabdus and Photorhabdus: two roads to the same destination. Molecular Microbiology, 64, 260-268.

Guo, L., Fatig, R. O., Orr, G. L., Schafer, B. W., Strickland, J. A., Sukhapinda, K., Woodsworth, A. T., \& Petell, J. K. (1999). Photorhabdus luminescens W-14 Insecticidal Activity Consists of at Least Two Similar but Distinct Proteins: purification and characterization of toxin a and toxin B. The Journal of Biological Chemistry, 274, 9836-9842.

Holmes, N. A., Innocent, T. M., Heine, D., Bassam, A., Worsley, S. F., Trottmann, F., Patrick, E. H., Yu, D. W., Murrell, J. C., Schiøtt, M., Wilkinson, B., Boomsma, J. J., \& Hutchings, M. I. (2016). Genome Analysis of Two Pseudonocardia Phylotypes Associated with Acromyrmex Leafcutter Ants Reveals Their Biosynthetic Potential. Frontiers in Microbiology, 7, 1-17. DOI: $10.3389 /$ fmicb.2016.02073

Huang, L., Xie, J., Lv, B. Y., Shi, X. F., Li, G. Q., Liang, F. L., \& Lian, J. Y. (2013). Optimization of nutrient component for diesel oil degradation by Acinetobacter beijerinckii ZRS. Marine Pollution Bulletin, 76, 325-332.

Hurst, M. R. H., Glare, T. R., Jackson, T. A., \& Ronson, C. W. (2000). Plasmid-Located Pathogenicity Determinants of Serratia entomophila, the Causal Agent of Amber Disease of Grass Grub, Show Similarity to the Insecticidal Toxins of Photorhabdus luminescens. Journal of Bacteriology, 182, 5127-5138. 
Inglis, G. D., \& Lawrence, A. M. (2001). Effects of Serratia marcescens on the F1 Generation of LaboratoryReared Heliothis virescens (Lepidoptera: Noctuidae). Journal of Economic Entomology, 94, 362-366.

Jeong, H. U., Mun, H. Y., OH, H. K., Kim, S. B., Yang, K. Y., Kim, I., \& Lee, H. B. (2010). Evaluation of insecticidal activity of a bacterial strain, Serratia sp. EML-SE1 against diamondback moth. Journal of Microbiology, 48, 541-545.

Kanfra, X., Liu, B., Beerhues, L., Sørensen, S. J., \& Heuer, H. (2018). Free-Living Nematodes Together with Associated Microbes Play an Essential Role in Apple Replant Disease. Frontiers in Plant Science, 9, 1666. DOI: $10.3389 /$ fpls.2018.01666

Kaltenpoth, M., \& Engl, T. (2014). Defensive microbial symbionts in Hymenoptera. Functional Ecology, 28(2), 315-327.

Kaltenpoth, M., Yildirim, E., Gürbüz, M. F., Herzner, G., \& Strohmd, E. (2012). Refining the roots of the Beewolf-Streptomyces symbiosis: antennal symbionts in the rare genus Philanthinus (Hymenoptera, Crabronidae). Applied and Environmental Microbiology, 78(3), 822-827.

Kehres, J., Denon, D., \& Mauleon, H. (2001). A simple technique to estimate, in situ, population densities of an entomopathogenic nematode (Heterorhabditis indica) in sandy soils. Nematology, 3(3), 285-287.

Kroiss, J., Kaltenpoth, M., Scheneider, B., Schwinger, M., Hertweck, C., Maddula, R. K., Strhom, E., \& Svatoš, A. (2010). Symbiotic streptomycetes provide antibioticcombination prophylaxis for wasp offspring. Nature Chemical Biology, 6, 261-263.

Leite, L. G. (2011). Aplicação de nematóides entomopatogênicos e resultados de programas na américa latina. In A. A. Saenz, J. C. Lopez-Nuñez, \& L. A. Galindo (Eds.), Experiencias con Nematodos Entomopatógenos: Retos y Oportunidades de Uso en America Latina (pp. 19-33). Bogotá, Colombia: CYTED.

Lobo-Echeverri, T., Salazar, L. C., Hernández, A. \& OrtizReyes, A. (2016). Effects of Capsicum baccatum and C. frutescens against Atta cephalotes (Hymenoptera: Formicidae) and the symbiotic fungus Leucoagaricus gongylophorus. Revista Colombiana de Entomología, 42, 137-145.

López, E., \& Orduz, S. (2003). Metarhizium anisopliae and Trichoderma viride for control of nests of the fungusgrowing ant, Atta cephalotes. Biological Control, 27, 194-200.

Madden, A. A., Grassetti, A., Soriano, J. A. N., \& Starks, P. T. (2013). Actinomycetes with Antimicrobial Activity Isolated from Paper Wasp (Hymenoptera: Vespidae: Polistinae) Nests. Environmental Entomology, 42(4), 703-710.
Matarrita-Carranza, B., Moreira-Soto, R. D., MurilloCruz, C., Mora, M., Currie, C. R., \& Pinto-Tomas, A. A. (2017) Evidence for Widespread Associations between Neotropical Hymenopteran Insects and Actinobacteria. Frontiers in Microbiology, 8, 1-17. DOI: 10.3389/fmicb.2017.02016

Marsh, S. E., Poulsen, M., Gorosito, N. B., Pinto-Tomás, A., Masiulionis, V. E., \& Currie, C. C. (2013). Association between Pseudonocardia symbionts and Atta leaf-cutting ants suggested by improved isolation methods. InternatIonal Microbiology, 16, 17-25. DOI: $10.2436 / 20.1501 .01 .176$

Montoya-Lerma, J., Giraldo-Echeverri, C., Armbrecht, I., Farji-Brener, A., \& Calle, Z. (2012). Leaf-cutting ants revisited: Towards rational management and control. International Journal of Pest Management, $58,225-247$.

Nechitaylo, T. Y., Westermann, M., \& Kaltenpoth, M. (2014). Cultivation reveal physiological diversity among defensive 'Streptomyces philanthi'symbionts of beewolf digger wasps (Hymenoptera, Crabronidae). BMC microbiology, 14(202), 1-15. DOI: 10.1186/s12866-014-0202-x

Nishanth, K. S., Mohandas, C., \& Nambisan, B. (2013). Purification of an antifungal compound, cyclo (1-Prod-Leu) for cereals produced by Bacillus cereus subsp. thuringiensis associated with entomopathogenic nematode. Microbiological Research, 168, 278-288.

Nishanth, K. S., Nath, V. S., Chandran, P. R., \& Nambisan, B. (2014). Cyclic dipeptides from rhabditid entomopathogenic nematode-associated Bacillus cereus have antimicrobial activities. World Journal of Microbiology \& Biotechnology, 30(2), 439-49. DOI:10.1007/ s11274-013-1461-7

Nielsen-LeRoux, C., Gaudriault, S., Ramarao, N., Lereclus, D., \& Givaudan, A. (2012). How the insect pathogen bacteria Bacillus thuringiensis and Xenorhabdus/ Photorhabdus occupy their hosts. Current Opinion in Microbiology, 15(3), 220-231. DOI: 10.1016/j. mib.2012.04.006

Nollmann, F. I., Heinrich, A. K., Brachmann, A. O., Morisseau, C., Mukherjee, K., Casanova-Torres, Á. M., Strobl, F., Kleinhans, D., Kinski, S., Schultz, K., Beeton, M. L., Kaiser, M., Chu, Y-Y., Phan, K. E. L., Thanwisai, A., Bozhüyük, K. A. J., Chantratita, N., Götz, F., Waterfield, N. R., Vilcinskas, A., Stelzer, E. H. K., Goodrich-Blair, H., Hammock, B. D., \& Bode, H. B. (2015). A Photorhabdus Natural Product Inhibits Insect Juvenile Hormone Epoxide Hydrolase. ChemBioChem, 16, 766-771.

Oliveira, M. (2006). Controle de formigas cortadeiras (Hymenoptera: Formicidae) com produtos naturais (Tesis de Doctorado). Universidade Estadual Paulista, Brasil. 
Ortiz, A., \& Orduz, S. (2001). In vitro evaluation of Trichoderma and Gliocladium antagonism against the symbiotic fungus of the leaf-cutting ant Atta cephalotes. Mycopathologia, 150, 53-60.

Patil, C. D., Patil, S. V., Salunke, B. K., \& Salunkhe, R. B. (2011). Prodigiosin produced by Serratia marcescens NMCC46 as a mosquito larvicidal agent against Aedes aegypti and Anopheles stephensi. Parasitology Research, 109, 1179-1187.

Poulsen, M., \& Currie, C. R. (2010) Symbiont Interactions in a Tripartite Mutualism: Exploring the Presence and Impact of Antagonism between Two FungusGrowing Ant Mutualists. PLOS ONE 5(1), 8748. DOI: 10.1371 journal.pone. 0008748

Ramadhar, T. R., Beemelmanns, C., Currie, C. R., \& Clardy, J. (2014). Bacterial symbionts in agricultural systems provide a strategic source for antibiotic discovery. The Journal of Antibiotics, 67, 53-8.

Rodriguez, J., Montoya-Lerma, J., \& Calle, Z. (2015). Effect of Tithonia diversifolia Mulch on Atta cephalotes (Hymenoptera: Formicidae) Nests. Journal of Insect Science, 15, 32-32.

Romero-Tabarez, M., Jansen, R., Sylla, M., Lünsdorf, H., Häussler, S., Santosa, D. A., Timmis, K. N., \& Molinari, G. (2006). 7-O-malonyl macrolactin A, a new macrolactin antibiotic from Bacillus subtilis active against methicillin-resistant Staphylococcus aureus, vancomycin-resistant enterococci, and a small-colony variant of Burkholderia cepacia. Antimicrobial Agents and Chemotherapy, 50, 1701-1709.

Ruffner, B., Péchy-Tarr, M., Ryffel, F., Hoegger, P., Obrist, C., Rindlisbacher, A., Keel, C., \& Maurhofer, M. (2013). Oral insecticidal activity of plant-associated pseudomonads. Environmental Microbiology, 15, 751-63.

San-Blas, E., Carrillo, Z., \& Parra, Y. (2012). Effect of Xenorhabdus and Photorhabdus bacteria and their exudates on Moniliophthora roreri. Archives of Phytopathology and Plant Protection, 45, 1950-1967.

SAS Institute Inc. (2004). SAS/STAT ® 9.1 User's Guide. Cary, NC: SAS Institute.

Schneider, C. A., Rasband, W. S., \& Eliceiri, K. W. (2012), $\mathrm{NIH}$ Image to ImageJ: 25 years of image analysis. Nature methods, 9(7), 671-675

Stock, S. P. (1998). Sistemática y biología de nematodos parásitos y asociados a insectos de importancia económica. Argentina: Universidad Nacional del Litoral.
Stock, S. P., \& Goodrich-Blair, H. (2012). Nematode parasites, pathogens and associates of insects and invertebrates of economic importance. In L. A. Lacey (Ed.), Manual of Techniques in Invertebrate Pathology (pp. 373-423). Cambridge, EE.UU: Academic Press.

Tambong, J. T. (2013). Phylogeny of bacteria isolated from Rhabditis sp. (Nematoda) and identification of novel entomopathogenic Serratia marcescens strains. Current Microbiology, 66(2), 138-44. DOI: 10.1007/ s00284-012-0250-0

Tambong, J. T., Xu, R., Sadiku, A., Chen, Q., Badiss, A., \& Yu, Q. (2014). Molecular detection and analysis of a novel metalloprotease gene of entomopathogenic Serratia marcescens strains in infected Galleria mellonella. Canadian Journal of Microbiology, 60, 203-9.

Tonhasca, J. A., Bragança, M. A. L., \& Erthal, J. M. (2001). Parasitism and biology of Myrmosicarius grandicornis (Diptera, Phoridae) in relationship to its host, the leaf-cutting ant Atta sexdens (Hymenoptera, Formicidae). Insectes Sociaux, 48, 154-158.

Verma, M., Brar, S. K., Tyagi, R. D., Surampalli, R. Y., \& Valéro, J. R. (2007). Antagonistic fungi, Trichoderma spp.: Panoply of biological control. The Biochemical Engineering Journal, 37, 1-20.

West, T. P. (2014). Pyrimidine nucleotide synthesis in Pseudomonas nitroreducens and the regulatory role of pyrimidines. Microbiological Research, 169, 954-8.

White, G. F. (1927). A method for obtaining infective nematode larvae from cultures. Science, 66(1709), 302-3. doi.org/10.1126/science.66.1709.302-a

Yeates, G., Ferris, H., \& Moens, T. (2009). The Role of Nematodes in Ecosystems. In M. J. Wilson \& T. Kakouli-Duarte (Eds.), Nematodes as environmental indicators (p. 352). CABI Pub.

Yek, S. H., Nash, D. R., Jensen, A. B., \& Boomsma, J. J. (2012) Regulation and specificity of antifungal metapleural gland secretion in leaf-cutting ants. Proceedings. Biological sciences Royal Society, 279(1745), 4215-4222. DOI: $10.1098 /$ rspb.2012.1458

Zhang, C.-X., Yang, S.-Y., Xu, M.-X., Sun, J., Liu, H., Liu, J.-R., ... Zhang, K.-Y. (2009). Serratia nematodiphila sp. nov., associated symbiotically with the entomopathogenic nematode Heterorhabditidoides chongmingensis (Rhabditida: Rhabditidae). International Journal of Systematic and Evolutionary Microbiology, 59(7), 1603-1608. DOI: 10.1099/ijs.0.003871-0 